\title{
An Examination of the Nexus between Environmental Knowledge and Environmental Learning Processes
}

\author{
Christina Chitsiga and Ingrid Schudel
}

\section{Introducing the study}

Previous chapters in this book have discussed the complexity of environmental content (see Schudel and Lotz-Sisitka, Chapter 2; Isaacs and Olvitt, Chapter 4) and Chapter 8 (Schudel) has highlighted the significance and key elements of active and critical approaches to learning. The primary purpose of this chapter is to draw these two approaches together; that is, to explore the nexus of environmental content and environmental learning processes.

Environmental content faces challenges in many curricula internationally as, according to Grossman (1995, in Cutter-Mackenzie \& Smith 2003), teachers tend to teach well that which they know, and are not confident when it comes to teaching content with which they are not familiar. Findings from environmental education research have shown that unfamiliarity is a problem in South Africa as teachers lack environmental and sustainability content knowledge due to the fact that this content is new (LotzSisitka 2011; Fundisa for Change Programme 2013). Lotz-Sisitka (2009) reports cases in which teachers' recourse has been to rely on memories linked to prior curricula or lifeworld experiences to drive the learning processes of environmental content in the curriculum, with minimal reference to the curriculum framework, structure, content or assessment methods and standard. Thus, according to Lotz-Sisitka (2009) teaching practices are not providing adequate access to knowledge in the contemporary world 
as framed by curricula. This appears to be filtering through to learner achievement; for example, findings from a South African National Diagnostic Matric Exam for 2013 report showed a lack of content understanding in most of the subjects that have a focus on environmental content, such as Life Sciences and Geography (Mandikonza \& Lotz-Sisitka 2016).

However, even familiarity and confidence with environmental content is not sufficient to improve education for sustainable development (ESD). Concurrent with the need for understanding the complex content, is establishing pedagogies that support the designing of 'teaching and learning in an interactive, learner-centered way that enables exploratory, action-oriented and transformative learning' (Unesco 2014: 12). Spork (1992) and Fien (1993) both note an emphasis in literature on how the teaching approaches of teachers can affect the way in which content (environmental content in the case of this study) is understood by learners, as education is seen as a continuous interpretation of the curriculum by teachers (Stables 2004).

Exploring the nexus between environmental content and environmental learning processes has been informed by the concept of pedagogical content knowledge (PCK). In terms of PCK thinking, an educator's knowledge needs to go 'beyond knowledge of subject matter per se to the dimension of subject matter knowledge for teaching and ways of representing and formulating the subject that make it comprehensible to others' (McEwan \& Bull 1991: 324). An interest in PCK is explicit in the South African context, with the South African Minimum Requirements for Teachers specifying the development of 'specialised pedagogical content knowledge, which includes knowing how to represent the concepts, methods and rules of a discipline in order to create appropriate learning opportunities for diverse learners' (South Africa DHET 2011: 10). Employing PCK in this study meant exploring an interest in how complex environmental content plays out when active and critical approaches to learning are mobilised through typical ways of representing and formulating subject matter in the field of ESD.

The research explored this nexus through an empirical study of teacher mediation strategies in two Life Sciences classrooms in South Africa. For full understanding of these teachers' practices, there was also a need to acknowledge that expected outcomes do not always play out in classroom practice. Thus, the second purpose of the chapter is to develop an understanding of the enabling and constraining factors that influence the emergence of active and critical approaches in classroom practice.

Ultimately, the study sought to explore possible strategies to inform and strengthen classroom practices, particularly in the teaching of the environmental content in the curriculum. The study examined the teacher-mediating strategies through the following research question:

How are active and critical learning pedagogical strategies enabled and constrained at the nexus of environmental content and environmental learning processes in Grade 11 Life Sciences classrooms? 
From the research question the following goals were derived:

- To explore the nexus of teachers' content knowledge and teaching strategies with respect to environmental learning in the Grade 11 Life Sciences.

- To establish the architectural factors (cultural-discursive, materialeconomic and socio-political) that enabled and constrained the teachers' implementation of active and critical teaching strategies.

\section{Constructing a framework for reviewing environmental content and pedagogical knowledge}

Given that the nature of environmental content is contested and ideological, sociohistorical, tangible and demonstrable, and transformational, this research sought to explore how typical ESD pedagogies engage such knowledge foundations. To achieve the first research goal, the study used four pedagogical sensitising constructs from the field of environmental education for viewing mediation of environmental knowledge construction in Life Science classrooms. These pedagogical sensitising constructs: deliberation, situating story, proximity experience and practical reasoning, were drawn from Lotz-Sisitka and O'Donoghue's (2006) open process learning framework for environmental learning. This framework described teaching strategies which promoted active and critical approaches to learning. These sensitising constructs, as well as their relational process, are presented in Figure 1.

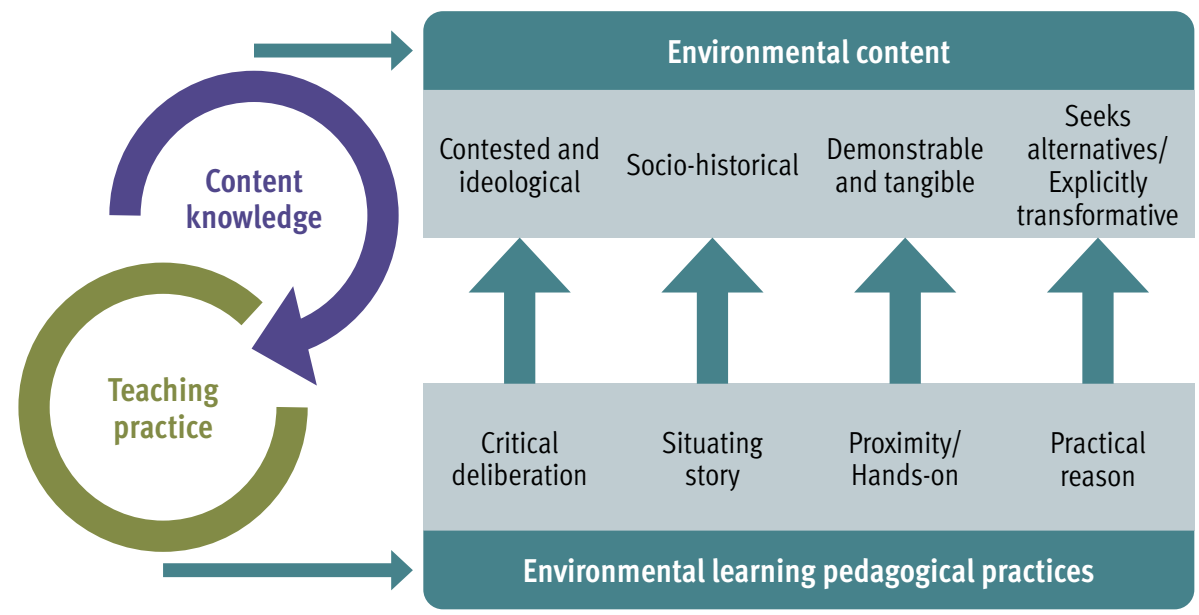

Figure 1. The representation of environmental pedagogies in relation to the nature of environmental content (elaborating on Lotz-Sisitka \& O’Donoghue 2006)

The four pedagogical sensitising constructs are outlined in the bottom part of the diagram, while the top part considers the environmental content that feeds into each. 
This is in an attempt to explore the nexus of teachers' content knowledge and teaching practice (that is the mediation of learning). Thus, the diagram has four nexus points:

- The contested nature of environmental knowledge meeting pedagogies requiring critical deliberation in classrooms. Here, ideological positions regarding environmental content are discussed and weighed up with value-based consideration of possible inequalities, compromises and trade-offs.

- Demonstrable and tangible knowledge meeting pedagogies requiring hands-on proximity encounters.

- Socio-historical context of environmental knowledge. This includes contextual knowledge of how formal Life Sciences content came to be. It also includes everyday, intergenerational and indigenous knowledges. This is where the evolution of knowledge meets pedagogies requiring situating stories.

- Transformative knowledge illustrating alternatives meeting pedagogies requiring practical reasoning. That is as a process of know-how, where there is an iterative relationship between change-orientated content knowledge and sustainability practices in a process of what Lotz-Sisitka and O'Donoghue (2006) term 'reasonable practice'. With practical reasoning, reflection about action itself directly moves people to act, thus developing reflective thinking as environmental content is being mediated. Practical reasoning, according to Jickling et al. (2006), is a process of self-validation allowing students to re-evaluate and re-imagine their lives.

\section{Reviewing the enablements and constraints of classroom implementation of ESD}

The study is framed by practice theory as proposed by Schatzki (2005) and the theory of practice architectures (Kemmis \& Heikkinen 2011) which elaborated on practice theory. Practices architectures were first articulated by Kemmis and Grootenboer (2008) who argued that practices are shaped not solely by intentional action and practice knowledge of participants but also by circumstances and conditions 'external' to them, due to: pre-existing cultural-discursive (concerned with the language of teaching and learning or language of the environmental field); material-economic (concerned with resources of teaching and learning); and social-political arrangements (concerned with policy guiding teaching and learning as well as organisational rules and regulations in teaching and learning institutions). These architectural arrangements shape the content and conduct of a practice that is comprised of the distinctive sayings, doings and relatings that occur in a particular kind of practice. The theory of practice architectures, developed from practice theory by Schatzki (2005) and Kemmis and Grootenboer (2008) helped to give insight into Goal 2 of the study. 


\section{Research methodology}

\section{Data generation process}

Two Grade 11 Life Science teachers (colleagues of the first author) were respondents for this study. The teachers chose to remain anonymous in the reporting of this study. However, for purposes of contextualising the study, we note here that the teachers, who were teaching in the same district as the first author, were from two coastal schools within the Ndlambe (Port Alfred) area of the Sarah Baartman district in the Eastern Cape province of South Africa.

The study's qualitative orientation enabled engagement with teachers in contextenabling first-hand encounters and in-depth analysis and understanding. A case-study approach enabled empirical inquiry, investigating a phenomenon within a real-life context (Baxter \& Jack 2008). This approach required continuous engagement between the researcher and the research participants.

Various data generation techniques were used in this study. Semi-structured interviews with each teacher elicited data about their contexts, practices (sayings, doings and relatings about their mediating practices), as well as the architectures influencing these practices. Questions were specifically designed to elicit information in relation to the pedagogical sensitising constructs of interest to the study.

Four lesson observations per teacher were conducted during the four-week duration of the environmental content coverage as set out in the Life Sciences curriculum. Lesson observations enabled generation of first-hand data and accounts of teacher approaches to mediating ESD. They also provided evidence of the practice architectures in each one of the schools in the research study.

Lesson observations were video recorded with Iris Connect technology which enables researcher and teacher participants to log on to a website and retrieve the saved lesson. This made possible the retrieval of data missed during the observations and enabled lesson recall with teachers during stimulated-recall interviews (Patton 2000). Such interviews assist in retrieving of memories, as well as enabling participants to explain their decision-making (Slough 2001; Mackey \& Gass 2005; Sime 2006). This strategy, together with the context-sensitive lens of practice architectures, added to the rigour of case-study research thus ensuring that the researchers did not impose naive or context-blind interpretations onto teacher practice. Discussions with teachers during stimulated interviews were voice recorded for detailed recording of data.

\section{Data analysis}

The analytical tool (presented in Table 1) placed sensitising constructs from the LotzSisitka and O'Donoghue (2006) open process framework for environmental learning, in a matrix against the theory of practice (Schatzki 2005) and the theory of practice architectures (Kemmis \& Heikkinen 2011). 
Table 1. Analytical framework combining practice theory and an open process framework for environmental learning

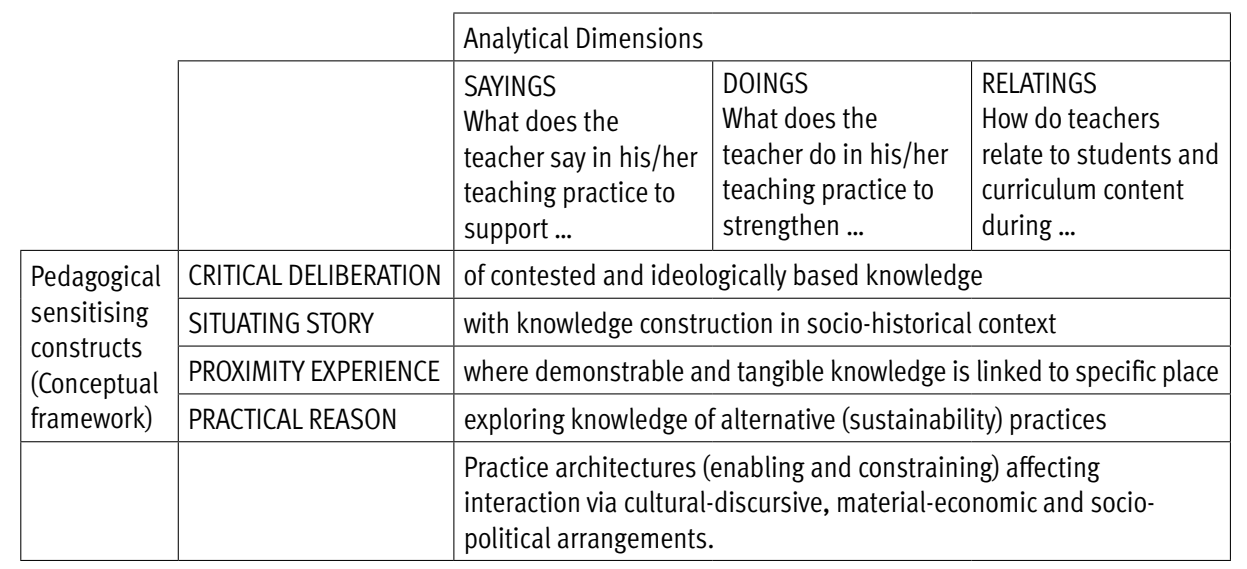

\section{Research findings and discussion}

\section{Case Study 1}

In her first lesson, Teacher 1 encouraged critical deliberation. She discussed the curriculum focus of water availability, under the topic of 'human impact', thus: 'The resources of South Africa are actually in short supply. And if the economy grows as they expect and the population grows as they expect, the demand for water will not be sustainable.' In the observation of the first teacher's lesson, her discussions focused on economic and industrial practices; poor practices and management; and ecological disturbances and geographical factors, which are suggested in the CAPS curriculum under human impact. She introduced similar factors when discussing water quality (listed under the same CAPS topic) thus: 'In this case most of the water is actually polluted by humans by industrial influence, domestic and commercial usage, by mine drainage and so that is quite bad and we should look into how to fix that.' This discussion illustrates the explicitly ideological nature of environmental content, with specific human practices being labelled as 'bad' and with a call for change emerging from this. In addition, through encouraging debate on ideological standpoints, she added to the discussion on water availability: 'Is water equally available? Let us discuss this idea.' Significantly, this political concern about unequal access to water is one of the few dimensions regarding water not raised by the CAPS curriculum. Yet equal access to water is a critical concern in South Africa, as illustrated by statistics that report that 'although $45 \%$ of the population has water access in their dwelling this ranges from $0.07 \%$ to $100 \%$ at ward level, with a high level of inequality' (Cole et al. 2018: 37).

Discussions about human impact are inherently critical but abstractions can make it difficult to fully understand the complexities and develop the skills of 'weighing up' 
and discussing 'trade-offs' - thus limiting the depth of critical engagement. Situating stories with specific cases in a specific place and time and with due consideration for socio-historical underpinnings can therefore operate to strengthen critical deliberation. For example, in the stimulated recall interview, the teacher described how,

I tried to include examples of things that the learners and their parents do that directly interfere with the environment, such as cutting down trees, dumping rubbish in undesignated grounds and how they dispose waste. The re-use of water particularly turned out to be quite a hot debated topic.

She showed the learners a situating story - a video of polluted water and its effect on a community in another province, which she said helped learners relate to pollution in their own town. To quote the educator: 'This town has had water issues being talked about a lot so it would only be good to bring learners to that reality that this happens in their context and perhaps they can then learn from this.' Situating her lessons in local context, she discussed the town's high salt-content levels in the water. She also discussed climate change and made links to the recent floods experienced in the town. Illustrating how that situating story had resonated with the learners, she reported their own example that they had offered: 'They mentioned that people, especially in the informal settlements, live off the fish that they catch in the river. If you keep water in a reservoir there is not enough water in the stream and it will affect the fish. If there is a flood it will affect them as they may not be able to catch fish, this will force them to move elsewhere, where they can make a living. And you will always find people living next to water supply.'

She illustrated that the inclusion of local issues in her teaching was not a 'once-off' activity, implying a good grasp of local potential that could be included in the topic of 'human impact' in the CAPS:

A lot of examples are ... from what happens in our direct environment where learners live, such as garbage and water pollution. Even the issue of abalone poaching and alien plants around their homes.

While a hands-on proximity experience was not directly observed in this study, the teacher indicated that she planned on 'doing a water quality expedition on the [local river] and this would also develop their scientific skills.' The Life Sciences curriculum includes a section where water-quality tests and knowledge of the effects of pollution of water are required. To prepare learners for the excursion, the teacher used audio-visual material which enabled learners to make the link between what they had learnt earlier in a section on micro-organisms and the water quality section they were currently engaged with. Proximity experience was clearly not an approach that was foreign to this teacher who asked learners in class: 'Remember when we went to a recently cleared area of the school and looked at all the possible effects the cutting down of trees may 
have had on the process of photosynthesis and the environment?'

Practical reasoning is the fourth sensitising construct. In the section above, we argued that a situating story is an important aspect of critical deliberation. Building on this, processes such as reimagining, re-evaluating and the search for alternatives that are reasonable to institute in practice are also critical for teaching strategies trying to develop practical reason. Lotz-Sisitka and O'Donoghue argue that: 'Young learners are quick to work out how one way is better than another but are seldom much good at the critical analysis of prevailing orientation without any experience of alternatives' (2006: 12).

The first teacher showed an interest in seeking alternatives with her comment that: 'Through teaching others about the environmental issues, we can have a cleaner and safer environment. I am actually honoured to be part of teaching learners who preserve and protect our environment.' However, in the observed lessons there was no evidence of a search for alternatives, notwithstanding that these may have been included in further lessons not observed in the course of this research.

\section{Case Study 2}

Teacher 2 supported critical deliberation processes by pushing for understanding of the science behind environmental issues. For example, during one of the presentations he asked: 'The factories release heat which gets trapped within the ozone layer. What is this referring to exactly and tell the class why is it bad? What is the reason behind this happening? Tell the class more.' This quote highlights two things: first, it is another example of the ideological nature of ESD. Yet an ideological standpoint on ecological impact (the problematic of global warming) is easier to critique than a complex social-ecological development problem (e.g. nuclear power or coal-driven power as a solution for remedying a country's electricity supply shortfall). The CAPS's focus on 'human impact' therefore does not lend itself to more critical engagement through asking learners, for example, to consider the question of whether addressing South Africa's electricity shortfall and access for all necessarily must impact negatively on the environment.

The quote also highlights one of the problems mentioned above of teachers' limited content understanding (Lotz-Sisitka 2011). Misconceptions among school-going and university students and teachers in training about the relationship between the ozone layer and climate change have long been documented and are still ongoing, as shown by the recent research by Gungordu, Yalc1n-Celik and Kilic (2017). While the teacher was not incorrect that the ozone layer traps heat (United Kingdom. Department of Environment Food and Rural Affairs n.d.), the relationship between ozone and heat is complex and it would be better to focus simply on how greenhouse gases in the troposphere (a different atmospheric layer to where the ozone is found) impact on climate change.

The teacher issued an invitation to the groups to criticise or add relevant information they deemed necessary to the presentations. In the stimulated recall interview, he 
mentioned that his choice of approach was informed from his own experiences, saying that if learners were not probed via verbal interaction or in written tasks they became passive. To support this, he said:

Learners just sit and don't think through their answers or what the teacher would have asked. There is no considered thinking on their part, but this time I kept digging deeper into their responses asking why and how. The level at which they answered as well as the sort of questions asked, they showed deep thought and engagement with the content.

Teacher 2 supported situated learning in the homework task exploring case studies of climate change on the African continent, for example, a case study on how climate change is fuelling malaria in Kenya, or a worksheet on water-borne diseases affecting our South African context. This teacher also enriched the discussion through everyday examples to which the learners could relate. For example, he argued:

You are what your surrounding is like. Hence what you do in the community around your house reflects on you especially where environmental issues are concerned. If you have an illegal dump outside your house, it is calling for all sorts of diseases and I make such links possible to learners.

While proximity experience was not observed in this research, a previous visit to the local beach area and river to study water pollution due to the presence of red tide was one of the references made by Teacher 2 to enhance proximity experience - although, notably, red tide is not a 'human impact' issue, but a seasonal fluctuation of algal blooms influenced by salinity, temperature and wind (see Figure 2). He acknowledged the need for learners to have a hands-on experience of learning. His beach and river visit encounter served this purpose as he noted that:

We went to visit the beach and river and it made sense now when we spoke of water pollution and water quality as some of the effects of that red tide could be linked by the learners to this section. So it is that ability to give learners the closeness to experiences especially within their context that enables them to have a feel and make sense of this environmental content.

Learners were then able to incorporate this previous proximity experience into the discussion on 'human impact'.

As with Teacher 1, there was no evidence in the lessons observed of learners using practical reason to seek alternatives to the environmental issues presented in class. 


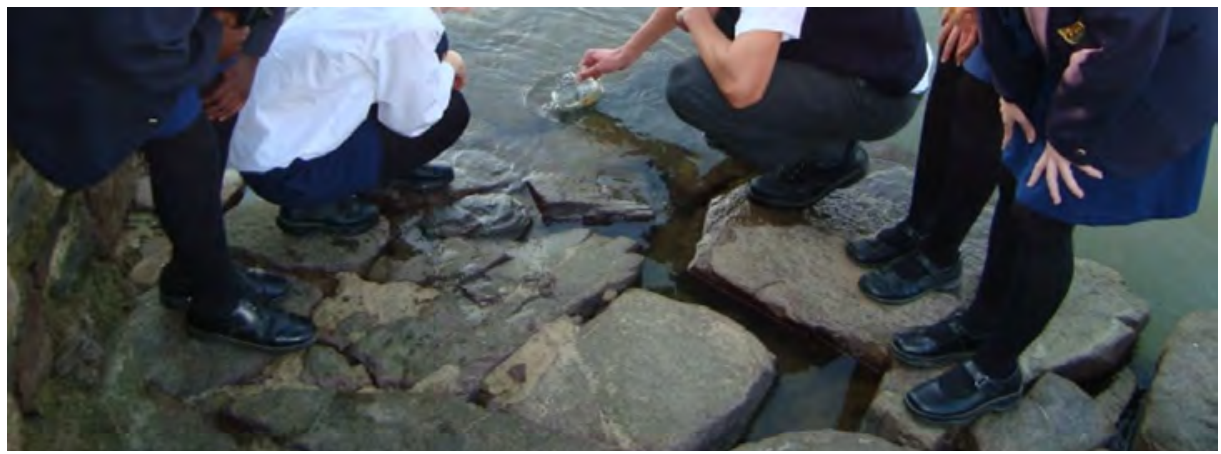

Figure 2. Previous outdoor river expedition led by Teacher 2 to test for water quality as affected by a red tide (photograph cropped to protect learner identity)

\section{Practice architectures as enabling and constraining teaching practice at the nexus of environmental content and environmental learning pedagogical practices}

\section{Critical deliberation of contested and ideological environmental content knowledge}

Teacher 1 indicated her limited exposure to and training for the environmental content of the curriculum (discourse of the environmental field). Teacher 2 noted materialeconomic constraints in the form of lack of photocopying machines for district staff (subject advisors) to copy teaching and learning material and a lack of cars to travel to schools, thus restricting ongoing training seminars and curriculum coverage monitoring to enhance teacher readiness for CAPS.

This lack of preparedness meant a need for preparing and sourcing information from elsewhere in order for Teacher 1 to supplement her lecture-style teaching practice. She stated that despite the fact that she was still a beginner teacher in the field she was familiar with some of the content knowledge and that this, to a certain extent, enabled her to mediate.

As an additional constraining factor, Teacher 1 and her learners use English as their second language. However, most of the available learning and teaching materials were in English, limiting both Teacher 1 and her learners. This meant that she found it difficult to articulate the content in a way that learners could easily understand, and this hampered mediation.

She used internet-based video resources containing relevant material on environmental issues to supplement her teaching. She went on to support her use of audio-visual material through arguing that,

Whenever I use internet-based materials I find it easier for the learners to relate and also to answer their questions. I get a feeling that it's learning together in a way, as we both watch the material and learn. 
Teacher 2's lessons were more strongly reliant on learner-led research. He was concerned about his own 'limited knowledge in some content areas'. However, he appeared confident enough in the discourse to be able to 'guide them during their discussions so as to not make them lose track of what's to be discussed'. In fact he appeared so confident with some of the content that he commented: 'Most of my students know how I get carried away when I'm busy teaching any topic therefore I would say that they rather chose to join me on this journey, sharing and discussing ideas. This helped me also not to wander off the topic.' It appears that this teacher's confidence was borne from years of experience in an alternative discourse - Geography and Adult Education - rather than in training or experiences in Life Sciences teaching per se. This enabled him to use questioning strategies to evoke 'deeper reflective thought in the learners'.

Giving more power to learners in classrooms can support learning. However, Teacher 2 highlighted that the multicultural set up in the school meant that working together and learning from one another did not flow easily. This was the reason for his choice of group work as a teaching method - to provide more opportunity for such intercultural dialogue. A socio-political concern for keeping power in the hands of the teacher can have equally convincing argument. For example, Teacher 1 argued: 'Well, I make use of minimum group work as I find it difficult to control the class or judge just how much of the actual learning is happening as I'm not with all the groups at the same time.'

\section{Situating story with knowledge construction in socio-historical context}

A resourceful teacher, Teacher 1 supported situating stories by gathering 'information of our environment to include in the lessons. This means the topic is a bit more 'real' to learning such as the water quality issue in the town.' Teacher 2 added that the use of local context was one strategy that could be used more to develop deeper engagement with the environmental content as most issues were prevalent in the communities in which learners found themselves.

Being in a multicultural environment and a dual-medium (English/Afrikaans) school, Teacher 2 used both languages as a medium of instruction. While leading critical deliberation, being fluent in both languages meant that he was easily able to code-switch, thus making the content better understood. However, situating stories can often be presented as written case studies. In this case, lack of familiarity with a language can become a barrier when 'comprehension and ability to read through the case studies are essential'.

\section{Proximity experiences exploring demonstrable and tangible knowledge}

The CAPS suggests 'Practical observation of ONE example of human influence on the environment in the local area' (South Africa DoE 2012: 51), thus supporting proximity experience. However, resource constraints means it is not always possible to take learners on excursions, as noted by Teacher 2 : 
There is also the issue of availability of resources, with not much extra teaching materials, transport to take learners for field trips and teachers or textbooks, that sort of thing, it then becomes difficult to fully and enjoyably make the learners excited about such topics.

He added:

I also think there are too few or no excursions or fieldtrips which would otherwise bring a real feel to the learners and enable them to carry out observations and experiments in the environment. It is part of their skills development as well which the syllabus requires them to attain but is currently being limited.

Teacher 2 furthermore reported that his planning of lessons and adherence to some of the expectations of the curriculum, such as field trips, were dependent on approval of these trips by schools and the district office.

\section{Practical reason drawing on transformative knowledge illustrating alternative sustainability practices}

Teacher 1 noted that the socio-political architecture of the prescriptive curriculum helped her in controlling what she would teach and how she would mediate. According to her, the CAPS document (South Africa DoE 2012) 'directly influences the delivery of certain topics in schools. It gives strict guidelines as to the topics to be discussed.' Openings are made in the CAPS curriculum for seeking sustainability alternatives, with sub-topics such as reducing carbon footprint; water purification and recycling; control of alien plant invasion; inclusion of indigenous knowledge on natural heritage and its sustainable use; searching for alternatives to poaching; prevention in soil and water pollution; and rehabilitation being among the listed sub-topics.

Yet, despite the curriculum imperative, the lessons covered for this research did not provide evidence of this important aspect being taught. Teacher 1 noted a desire for more help with biodiversity, saying: 'I would have loved some help with the section on endemic plants, their role, threats to them and what role citizens can play in their preservation.'

The problem-orientated discourse of the observed lessons, which avoided a search for problem-solving alternatives, may not be surprising. That is because, even though sustainability practices are listed in the CAPS, the main topic of 'human impact' emphasises problems above alternatives, and this is exacerbated by 'cause and consequence' as the opening interest line in the description of the topic, which thereafter hierarchically governs all further sub-topics.

More insight into the lack of a search for solutions comes from Teacher 2's critical observation that, 'one has to have a full understanding or at least familiarisation with the environmental content, otherwise you will not fully be able to implement it or 
develop ways to help intervene.' By this he is signifying that the different dimensions of active and critical pedagogies are linked, and he presents a perception that the critical and contested nature of environmental issues needs to be mastered before one can adequately address transformative pedagogical practices.

However, Lotz-Sisitka and O'Donoghue argue an alternative perspective, that one does not necessarily have to begin with a problem, suggesting a 'shift in focus from problem-centred approaches that depict the environment awash with complex problems to a more practical engagement with and practising of better ways of doing things' (2006: 12).

\section{Summary and conclusions}

The first aspect of this study dealt with teachers' PCK. A substantive pedagogical framing from an environmental learning perspective enabled a detailed exploration of the opportunities afforded at the nexus of teachers' environmental content knowledge and teaching strategies (in response to Research Question 1). The findings from Question 1 are summarised below in conjunction with the second aspect of this study, which was Question 2's interest in practice architectures and what enabled and constrained the emergence of the pedagogical practices described in response to Question 1. From these summaries, suggestions for curriculum changes, support materials and training are made.

The cases reveal that contested and ideological environmental content can be misleading if environmental knowledge of topics such as climate change is not accurate. This highlights the importance of ongoing interventions in strengthening teacher environmental content knowledge. Ideologically, environmental knowledge is complex and while it is easy to label practices that negatively impact on the environment as 'bad', teacher training should include critical deliberations of social-ecological complexities around questions of social justice and sustainable development. Notably, teachers drew on their Geographical knowledge to strengthen their effectiveness in the human impact topic of the Life Sciences curriculum and it is suggested that Life Sciences may be able to draw on inquiry strategies in the Geography curriculum to deepen this particular topic within the Life Sciences. Strategies such as 'why', 'how' and 'when' questions were highlighted as important for critical deliberation.

In order to support critical deliberation, training and support materials could strengthen environmental content knowledge by:

a) building on teachers' capacity for filling gaps in their knowledge with internet-based teaching materials;

b) building on their visions of themselves as life-long learners when resources and training programmes do not meet their needs;

c) supporting and strengthening their interest in learner-led research and intercultural dialogue in a way that will enable quality products 
from learners (e.g. through explicitly supporting critical thinking, inquiry and research strategies among learners);

d) and supporting their visions of themselves as critical thinkers who can guide learning in insecure knowledge contexts.

Teachers indicated an awareness of case studies relevant for supporting situating stories, particularly in the local context, as well as capacity for resourcing these case studies. Local case studies identified included abalone poaching, alien invasives around homes, and high salt water levels in local water supplies. Teachers should be encouraged to do more of this work, drawing on local news reports and local experts to gain insight into these topics. Teaching strategies to support situating stories rich with socio-historical context included 'comparative studies' and learner-led research and it is suggested that these strategies could be included in teacher training to support the human-impact topic. However, one difficulty identified with these contextualised situating stories is that by drawing on local newspapers and articles, you are not drawing on resources developed for the specific grade and group of learners with which you work, and the material is often exclusively in English, which, for second language learners, can make these cases difficult to follow. Thus teachers need to be supported in how to adapt and select case-study material that is accessible to second language learners.

Proximity experience was not demonstrated during this study but discussions of past activities and possible future activities provided insight for the study. This is a curriculum-driven need and deemed valuable and necessary by the teachers in this study. However, teaching resources as well as material-economic needs and logistical complexities were cited as reasons for limitations on this curriculum requirement. One teacher described field work where learners recorded local deforestation effects, illustrating a potential for developing tangible and demonstrable knowledge of human impact. However, not all field work was relevant to the specific topic at hand (red tide might be considered pollution, but is not an example of pollution caused by human impact). This suggests that teachers need field-work support material and suggestions of relevant studies to conduct which can be sufficiently generic to succeed in diverse South African contexts.

Evidence of practical reason and exploration of alternative sustainability practices was not well supported in the cases studies, despite teacher resourcefulness and creativity as described above. This could be because the curriculum makes suggestions for where alternative sustainability practices should be sought, but this is over-shadowed by a more dominant problem-orientated cause/effect representation of 'human impact' - as suggested even by the limitations in the title of this topic. Another suggestion made by one of the teachers was that limited knowledge of environmental complexity can limit understanding of appropriate responses. However, what emerges from this study is that a less linear and problem-orientated starting point for understanding humanenvironment relationships in the CAPS curriculum might enable a more transformative approach to support active and critical pedagogies in the Life Sciences. 


\section{References}

Ballantyne RR \& Packer JM (1996) Teaching and learning in environmental education: Developing environmental conceptions. The Journal of Environmental Education 27(2): 25-32. http://www. tandfonline.com/doi/abs/10.1080/00958964.1996.9941455

Baxter P \& Jack P (2008) Qualitative case study methodology: Study design and implementation for novice researchers. The Qualitative Report 13(4): 544-559. http://www.nova.edu/sss/QR/QR134/baxter.pdf.

Bertram C (2011) What does research say about teacher learning and the teacher knowledge? Implications for professional development in South Africa. Journal of Education 52: 3-26. http:// joe.ukzn.ac.za/Libraries/No_52_2011.What_does_research_say_about_teacher_learning_and_ teacher_knowledge_Implications_for_professional_development_in_South_Africa.sflb.ashx.

Bourdieu P (1998) Practical Reason: On the Theory of Action. Cambridge, MA: Polity Press

Carl AE (2009) Teacher Empowerment through Curriculum Development: Theory into Practice. 3rd edn. South Africa: Juta \& Company Ltd

Castro JE (2013) Water is not (yet) a commodity: Commodification and rationalization revisited. GOBACIT 2(1). http://hdl.handle.net/2027/spo.11217607.0002.103.

Cole MJ, Bailey RM, Cullis JD \& New MG (2018) Spatial inequality in water access and water use in South Africa. Water Policy 20(1): 37-52

Cutter-Mackenzie A \& Smith R (2003) Ecological literacy: The 'missing paradigm' in environmental education (Part One). Environmental Education Research 9(4): 497-524. http://www.tandfonline. com/doi/pdf/10.1080/1350462032000126131\#.VY5fjhuqro8

Edlund C (2011) Student perceptions of outdoor educational experiences. Unpublished doctoral thesis, Walden University, Minneapolis

Fien J (1993) Education for the Environment: Critical Curriculum Theorizing and Environmental Education. Geelong, Victoria: Deakin University Press

Fien J (2000) The learning for a sustainable environment project: A case study of action network for the teacher education. Australian Journal of Environmental Education 17: 77-86

Fundisa for Change Programme (2013) Fundisa for Change: Introductory Core Text. Environmental Learning Research Centre. Makhanda: Rhodes University. http://www.fundisaforchange.co.za/ wordpress/wp-content/uploads/2013/08/Introductory-Core Text.pdf

Gungordu N, Yalcin-Celik A \& Kilic Z (2017) Students' misconceptions about the ozone layer and the effect of internet-based media on IT. International Electronic Journal of Environmental Education 7(1): 1-16

Hemmings B, Kemmis S \& Reupert A (2013) Practice architectures of university inclusive education teaching in Australia. Professional Development in Education 39(4): 470-487

Janse van Rensburg E \& Mhoney K (2000) The spiral model of learning for sustainability. In: E Janse van Rensburg \& H Lotz-Sisitka (eds) Learning for Sustainability: An Environmental Education Professional Development Case Study Informing Policy and Practice. Johannesburg: Learning for Sustainability Project. pp. 41-69

Jickling B, Lotz-Sisitka H, O'Donoghue R \& Ogbuigwe A (2006) Environmental Education, Ethics and Action. A Workbook to Get Started. Howick: UNEP/Share-Net

Kemmis S \& Grootenboer P (2008) Situating praxis in practice: Practice architectures and the cultural, social and material conditions for practice. In: S Kemmis \& TJ Smith (eds) Enabling Praxis: Challenges for Education. Rotterdam: Sense Publishers. pp. 37-62

Kemmis S \& Heikkinen H (2011, September) Understanding professional development of teachers within the theory of practice architectures. European Conference of Educational Research 2011: Berlin, Germany

Lotz-Sisitka H (2009) Why ontology matters to reviewing environmental education research. Environmental Education Research 15(2): 165-175 
Lotz-Sisitka H (2011) National case study - teacher professional development with an education for sustainable development focus in South Africa: Development of a network, curriculum framework and resources for teacher education. Southern African Journal of Environmental Education 28: 30-65

Lotz-Sisitka H (2013) Quality education research: A conversation. M.Ed (Environmental Education) lecture notes, Rhodes University, Environmental Learning Research Centre, Makhanda

Lotz-Sisitka H \& Lupele J (2012) Learning for Today for Tomorrow: Sustainable Development Learning in Sub-Saharan Africa. Howick: SADC-REEP (Regional Environmental Education Programme)

Lotz-Sisitka H \& O'Donoghue R (2006) Situated environmental learning in Southern Africa at the start of the UN decade of education for sustainable development. Australian Journal of Environmental Education 22(1): 105-113

Lotz-Sisitka H \& Olvitt L (2009) South Africa: Strengthening responses to sustainable development policy and legislation. In: J Fien, R Maclean \& P Man-Gon (eds) Work, Learning and Sustainable Development. Springer: Dordrecht. pp. 319-328

Lotz-Sisitka H \& Songqwaru (2013) Fundisa for Change Implementation Plan 2013-2015. http:// www.fundisaforchange.com.

Mackey A \& Gass SM (2005) Second Language Research: Methodology and Design. New Jersey: Lawrence Erlbaum Associates, Inc.

Mandikonza C \& Lotz-Sisitka H (2016) Emergence of environment and sustainability education (ESE) in teacher education contexts in Southern Africa: A common good concern. Educational Research for Social Change 5(1): 107-130

McEwan H \& Bull B (1991) The pedagogic nature of subject matter knowledge. American Educational Research Journal 28(2): 316-334

Nelson Mandela Foundation and Education Policy Consortium (South Africa) (2005) Emerging voices: A Report on Education in South African Rural Communities. Cape Town: HSRC Press/ Nelson Mandela Foundation

Paavola S, Lipponen L \& Hakkarainen K (2004) Models of innovative knowledge communities and the three metaphors of learning. Review of Educational Research 74(4): 557-576

Patton MQ(2000) Qualitative Evaluation and Research Methods. 2nd edn. Thousand Oaks, CA: Sage Publications, Inc.

Rickinson M \& Lundholm C (2008) Exploring student's learning challenges in environmental education. Cambridge Journal of Education 38(3): 341-353

Schatzki TR (2005) The site of organizations. Organization Studies 26(3): 465-484

Shulman LS (1986) Those who understand: Knowledge growth in teaching. Educational Researcher 15(2): 4-14

Sime D (2006) What do learners make of teachers' gestures in the language classroom? International Review of Applied Linguistics in Language Teaching 44(2): 211-230

Slough L (2001) Using stimulated recall in classroom observation and professional development. Paper presented at the American Educational Research Association, Seattle, Washington

South Africa (1995) White Paper on Education and Training. Pretoria: Government Printers

South Africa Departments of Basic Education (DBE) and Higher Education and Training (DHET) (2011) Integrated Strategic Planning Framework for Teacher Education and Development in South Africa, 2011-2025. Pretoria: Government Printer

South Africa Department of Education (DoE) (2012) National Curriculum Statement Grades 1012. Curriculum and Assessment Policy Statement FET phase, Life Sciences. Department of Education, Pretoria

South Africa Department of Higher Education and Training (DHET) (2011) The Minimum Requirements for Teacher Education Qualifications. Government Gazette 583. Pretoria: Government Printer. pp. 3-59 
Spork H (1992) Environmental education: A mismatch between theory and practice. Australian Journal of Environmental Education 8: 147-166

Stables A (2004) Can education save the world? A response to David Gruenewald. Curriculum Inquiry 34(2): 233-240

Stevenson RB (2013) Researching tensions and pretensions in environmental / sustainability education policies: From critical to civically engaged policy scholarship. In: RB Stevenson, M Brody, J Dillion \& AEJ Wals (eds) International Handbook of Research on Environmental Education. New York: Routledge. pp. 147-155

Stone A (1998) The metaphor of scaffolding: Its utility for the field of learning disabilities. Journal of Learning Disabilities 3(4): 344-364

Taylor N \& Vinjevold P (eds) (1999) Teaching and learning in South African schools. Getting learning right: Report of the President's education initiative research project. Joint Education Trust. pp. 131162

United Kingdom. Department of Environment Food and Rural Affairs (n.d.) Ozone depletion and climate change. https://uk-air.defra.gov.uk/research/ozone-uv/moreinfo?view=deleption-climat echange\#: : text=Atmospheric ozone has two effects, trapping heat in the troposphere.

United Nations Educational, Scientific and Cultural Organization (Unesco) (2014) Roadmap for Implementing the Global Action Programme on Education for Sustainable Development. Paris: Unesco

Wals AEJ \& Jickling B (2009) A framework for young people's participation in sustainability. In: PB Corcoran \& PM Osano (eds) Young People, Education, and Sustainable Development. Exploring Principles, Perspectives, and Praxis. Wageningen: Wageningen Academic Publishers. pp. 77-85 